
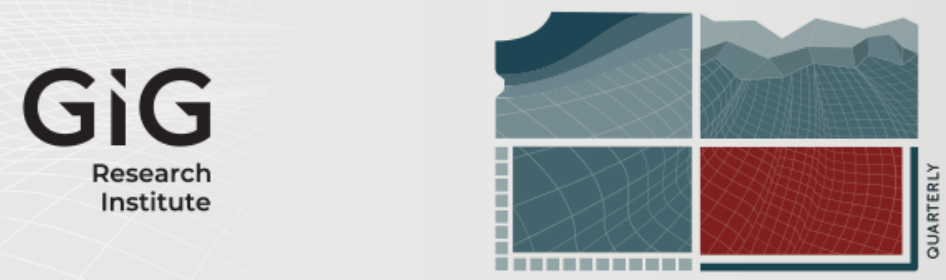

JOURNAL

OF

SUSTAINABLE

MINING

Volume 20 | Issue 2

Article 4

2021

\title{
Environmental, Health and Safety Intricacies of Artisanal Mining in the Gold-rich Landscapes of Karamoja, North-Eastern Uganda
}

Author(s) ORCID Identifier:

Eria Serwajja (iD 0000-0002-9133-4342

Paul Isolo Mukwaya (iD 0000-0002-0930-994X

Follow this and additional works at: https://jsm.gig.eu/journal-of-sustainable-mining

Part of the Explosives Engineering Commons, Oil, Gas, and Energy Commons, and the Sustainability Commons

\section{Recommended Citation}

Serwajja, Eria and Mukwaya, Paul Isolo (2021) "Environmental, Health and Safety Intricacies of Artisanal Mining in the Gold-rich Landscapes of Karamoja, North-Eastern Uganda," Journal of Sustainable Mining: Vol. 20 : Iss. 2 , Article 4.

Available at: https://doi.org/10.46873/2300-3960.1055

This Research Article is brought to you for free and open access by Journal of Sustainable Mining. It has been accepted for inclusion in Journal of Sustainable Mining by an authorized editor of Journal of Sustainable Mining. 


\title{
Environmental, Health and Safety Intricacies of Artisanal Mining in the Gold-rich Landscapes of Karamoja, North-Eastern Uganda
}

\begin{abstract}
Artisanal small-scale gold mining presents opportunities for Uganda's rural poor. However, it also poses serious environmental, health and safety challenges. A suite of data collection methods including interviews, focus groups discussions, water and soils sampling were used to examine the perceptions of miners on the status, prevalence and extent of mercury use in artisanal gold mining, mercury transit routes and toxicity levels of soils and water in Karamoja sub-region. It also explores the health, safety and environmental implications of artisanal small-scale gold mining in the sub-region. The findings show that trade and access to mercury is widespread; although trade in, access to and its use is highly secretive. Traders access mercury through a number of ways including smuggling across the porous borderline and formal, but covert, importation. Miners then discreetly access it through undercover sales in jewellery shops and in affluent gated communities in Uganda's capital, Kampala. Soil and water samples showed mercury levels that exceeded the minimum acceptable limits of $0.03 \mathrm{mg} / \mathrm{kg}$ and $0.006 \mathrm{mg} / \mathrm{l}$ respectively. Further, artisanal small-scale gold mining is associated with massive land clearances and landscape deformations. It has invariably scarred the countryside with piles of waste and uncovered pits that are a source of accidents and ideal breeding grounds for vectors.
\end{abstract}

\section{Keywords}

Artisanal Mining, Health and Safety, Environment, Karamoja, Uganda

\section{Creative Commons License}

This work is licensed under a Creative Commons Attribution 4.0 License.

\section{Cover Page Footnote}

We appreciate the contributions of the local communities and artisanal miners in the gold mining villages of Moroto and Amudat districts, and staff at Moroto and Amudat district local governments. Gratitude also goes to the Senior Environmental Officer for Amudat District Local government, Research Assistants, translators and anonymous reviewers for the insightful comments. This research benefitted from the generous funding provided by the Carnegie Corporation of New York under the Nurturing Emerging Research Leaders through Post-Doctoral at Training at Makerere University (NERLP) Project. 


\title{
Environmental, health and safety intricacies of artisanal mining in the gold-rich landscapes of Karamoja, north-eastern Uganda
}

\author{
Eria Serwajja ${ }^{a, *}$, Paul Isolo Mukwaya ${ }^{b}$ \\ ${ }^{a}$ Makerere University, Department of Development Studies, P.O. Box 7062 Kampala, Uganda \\ ${ }^{\mathrm{b}}$ Makerere University, Department of Geography, Geo-informatics and Climatic Sciences, P.O. Box 7062 Kampala, Uganda
}

\begin{abstract}
Artisanal small-scale gold mining presents numerous opportunities for Uganda's rural poor. However, it also poses serious environmental, health and safety challenges. A suite of data collection methods including interviews, focus groups discussions, water and soils sampling were used to examine the perceptions of miners on the status, prevalence and extent of mercury use in artisanal gold mining, mercury transit routes and toxicity levels of soils and water in Karamoja sub-region. It also explores the health, safety and environmental implications of artisanal small-scale gold mining in the sub-region. The findings show that trade and access to mercury is widespread; although trade in, access to and its use is highly secretive. Traders access mercury through a number of ways including smuggling across the porous borderline and formal, but covert, importation. Miners then discreetly access it through undercover sales in jewellery shops and in affluent gated communities in Uganda's capital, Kampala. Soil and water samples showed mercury levels that exceeded the minimum acceptable limits of $0.03 \mathrm{mg} / \mathrm{kg}$ and $0.006 \mathrm{mg} / 1$ respectively. Further, artisanal small-scale gold mining is associated with massive land clearances and landscape deformations. It has invariably scarred the countryside with piles of waste and uncovered pits that are a source of accidents and ideal breeding grounds for vectors.
\end{abstract}

Keywords: artisanal mining, mercury, gold, health and safety, environment, uganda

\section{Introduction}

$S$ cholarly debates on mining indicate a progressive increase in artisanal small-scale mining (ASM) in the global South [1,2]. ASM denotes informal mining processes conducted either by individuals or groups of people, or a mix of both, using simple tools such as sticks, sharp metallic objects, bare hands, shovels, jackhammers, and spades. It often operates outside of established state structures and legal regime [3], what de Soto [4] dubbed as "extra-legal" structures. The percentage contribution of ASM to the global mineral production has also increased as it supplies up to $80 \%$ of sapphire, $20 \%$ of gold and $20 \%$ of diamond [5]. Estimates indicate that artisanal miners have been increasing over the years, for instance, from 10 million in 1999 to 30 million people in 2013 [2,5]. More recent figures indicate that 40 million people are employed in ASM worldwide [6].

In many communities across the world, ASM provides direct and multiple benefits to the miners, their families and the broader community. For instance, artisanal small-scale gold mining (ASGM) is a livelihood source for millions especially in SubSaharan Africa $[7,8]$. It contributes to poverty reduction by providing employment opportunities to jobless youth and women who constitute the majority in many African countries. In the neo-liberal era, ASM has increasingly become a key social safety net for the rural poor and an alternative livelihood strategy where traditional sectors such as agriculture are failing due to a number of reasons

Received 5 February 2021; revised 4 April 2021; accepted 18 April 2021.

Available online 16 June 2021.

* Corresponding author.

E-mail addresses: eserwajja@gmail.com, eria.serwajja@mak.ac.ug (E. Serwajja), pmukwaya@gmail.com (P.I. Mukwaya). 
including low investment, climate change, poor farm inputs and increased pest and diseases [9].

ASM has gradually taken root in many rural communities where farming and agriculture are unable to sustain households. In Uganda, the sector has undergone legal and regulatory reforms amongst which include the formalization of artisanal and small-scale mining, which is the source of $90 \%$ of the country's minerals [10]. The number of people involved in ASM has been increasing over the years. While the previous estimates indicate that about 200,000 people are involved in the overall industry, with 20,000 specifically involved in gold mining [10,11], other scholars indicate that the number that is directly involved in ASM has doubled in the past few years to an estimated 400,000 in 2015 [12]. It is estimated that about 1.5 million people indirectly benefit from ASM and related activities (ibid). In the Karamoja sub-region of Uganda, poverty which stands at $82 \%$, unreliable climate and paucity of employment opportunities either in civil service or the private sector have left rudimentary mining of marble, limestone and gold as the only viable livelihood option and last resort for many Karamajongs [13]. Between 18,000 and 20,000 Karamojong men, women and children are involved in the mining of gold, gemstones, marble and other minerals [14].

Yet, underneath the labyrinth of positive socioeconomic change in the countryside where much of the mining takes place lies a myriad of negative socio-environmental impacts that could thwart and stifle the positive gains and advantages ASM has brought to this region. Violent conflicts, deepening poverty in the maze of an array of precious minerals, HIV/AIDS, prostitution, and child labour remain major concerns in the mining communities across the world [15]. In other contexts, food insecurity defines mineral-rich areas due to increasing withdrawal of labour from agriculture to ASM activities [16].

While gold is the most mined mineral in Uganda, it remains a rudimentary activity for artisanal miners with little or no large-scale investment [17]. The most prominent districts for ASGM are Mubende (Kitumbi and Kayonza sub-counties), Namayingo (Nakudi sub-county) gold fields on the shores of Lake Victoria in Eastern Uganda, the Buhweju gold fields in Western Uganda and Karamoja in the northern region [13]. Although there is substantial literature on ASM and its impact on the local communities in Uganda's mineral-rich landscapes [16,18-20], there is still a dearth of nuanced and evidence-based research that critically analyses its human, environmental, health and safety implications especially in remote areas such as Karamoja. The World Bank [6] has stressed the need for more scholarship on these issues by noting that "ASM remains one of the most poorly studied industries in the developing world".

In Uganda's case, much of the scholarship has focused on the impact of ASM on food security [16], child labour [21], women participation [11], HIV/ Aids [20] and sediment loading in water bodies [18]. It remains unclear how ASGM is invariably impacting on the fragile ecosystems, the health and safety of miners and mining communities in the mineral-rich landscapes of Karamoja - an acutely undeveloped area devoid of most basic infrastructure since it remains on the periphery of mainstream development. With specific focus on Moroto and Amudat districts, this study contributes to debates and discourses on the environmental, health and safety implications of ASGM activities.

The paper is divided into five parts. The first part provides an overview of ASM with specific emphasis on the selected case. The second part briefly reviews existing literature with the aim of teasing out the scope of previous studies on ASM especially in Africa, and the critical gaps in the current knowledge repository about ASM. The third part documents the methodology that was adopted to generate data and information for this study. The fourth part presents the findings of the study. The fifth part concludes the study.

\section{Artisanal small-scale mining and the environment: a review of literature}

ASM takes place in most mineral-rich countries throughout the developing world [6,22]. Although Africa has close to " $30 \%$ of the total world's mineral resources", only less than $5 \%$ is explored [23]. The continent will therefore continue to draw attention of miners and mining companies as other sources are gradually depleted, a scenario that will exacerbate the potential for mineral-induced conflicts. It is also inevitable that the greater proportion of future environmental, health and safety impacts of ASM will most likely and disproportionately affect the African continent. Experiences across the continent indeed show that ASM is accelerating ecosystem degradation, as opposed to enhancement, especially in the countryside where mineral extraction is occurring. Although various scholars argue that ASM positively contributes to social and economic development in the mineral-rich areas and provides more than $50 \%$ of the worldwide mineral requirements, it is equally 
evident that it presents serious challenges including air, land and water pollution [24].

In countries such as Ghana and Zambia, open-cast or surface mining which is often employed in the extraction of gold and copper ores respectively has vastly scarred the countryside landscapes. Miners often leave behind piles of waste earth and rocks regularly mixed with mercury, cyanide and other toxic materials - and uncovered mining pits of various shapes and sizes [25]. Environmental restoration and backfilling of mining pits and tunnels are hardly carried out to reinstate the ecosystems to the pre-mining state [26]. Open pits cause accidents for humans, domestic livestock and wildlife, and serve as breeding grounds for disease causing vectors such as mosquitoes. It has been documented that mercury used in gold processing invariably affects human health, pollutes land and fragile ecosystem particularly ground and underground water sources, with adverse impacts on the quantity and quality of people and aquatic life [27]. In other cases, ASM-induced soil erosion has increased the sediment load and turbidity of fresh water bodies $[18,28]$. In the Brazilian Amazon, over $70 \%$ of the mercury used in the artisanal mines ends up in the environment [1] and the mining pits are merely abandoned with no initiatives taken by artisanal miners to restore the landscape to its original pre-mining levels [29,30]. Further, deforestation and siltation continue to rise in the mining villages thereby affecting the flora and fauna in the Amazon and Beyond [1,29].

Aside from mercury, the use of cyanide by artisanal miners also poses severe challenges in the ASGM sector in the global South. In the Philippines, for instance, cyanide use has resulted in pollution of Ambalanga River which straddles across Sitio Dalisay in Gumatdang [31]. Gold smelting is done in residential areas and waste, including cyanide, is poured directly in drainage channels, gullies and the Ambalanga River. This has caused varied levels of pollution to the river, affecting aquatic life and related ecosystems. Further, most of the miners are exposed to cyanide because they do not use protective gear. Cyanide use has been associated with 'respiratory, digestive, hematologic and thyroid cancers' [31].

Regions that are endowed with substantial mineral deposits, such as the Congo Basin, central Africa region, and the Eastern rift valley - a corridor between Western Uganda and the Eastern borderline of the Democratic Republic of Congo (DRC) harbour the most sensitive ecosystems with rare flora and fauna. As such, ASM has invariably affected wildlife conservation given the informality, nature and mode of operation of the artisanal miners. Unregulated entry of artisanal miners into previously inaccessible rural mineral-rich areas that were once out of reach of the local population has increased pressure on land, encouraged illegal wildlife hunting and trade, and accentuated exploitation of other resources, such as, forests and related wildlife resources [23]. In Cameroon, ASGM in the Batouri community has heightened deforestation, vegetation clearance, soil erosion, air and water pollution. It has also exacerbated land degradation, leaching of dangerous pollutants from tailings and dumping of gold waste into the environmentally sensitive areas [32]. The situation is no different in Nigeria where ASM has accentuated land degradation, loss of vegetation, soil erosion and reduction of water quality [33]. The unprecedented environmental impacts of ASM have attracted attention, with some countries such as Zambia requiring mandatory Environmental Impact Assessments even where ASM operates beyond the State or formal regulatory frameworks [26].

The Minamata Convention on Mercury, adopted in October 2013, and came into force in 2017, has provided an important opportunity to catalyze global, regional and national intersectoral action needed to promote and protect the health and wellbeing of populations that depend on ASGM, especially with the use of mercury. In recognition of its associated human health and environmental impacts, mainly resulting from the use of mercury in the ASGM process, the Convention obligates Parties, as applicable, to develop public health strategies on the exposure of those involved in ASGM particularly where mercury is used [34]. Uganda is a signatory to the Minamata Convention which it ratified in March 2019. However, the current statutory scheme does not prohibit the importation of mercury but mandates clearance protocols for mercury imports associated with local industries such as ASGM, agriculture and cosmetics [35]. It appears that traders and miners take advantage of this to import mercury for use in the mines.

\section{Methodology}

\subsection{Study area}

The study was carried out in the Karamoja subregion that lies in the north eastern part of Uganda. In the sub-region, two districts were selected: Moroto and Amudat districts. Both districts share their eastern borderlines with the Republic of Kenya. The research was conducted in Rupa subcounty in Moroto district and Karita sub-county in 
Amudat district. Both research sites are mainly rural, with the dominant economic activities being nomadic pastoralism. In some areas, however, the local people also engage in subsistence agriculture. Much of the land in Karamoja is held under communal tenure but with sub-communal tenure arrangements including customary communal tenure for grazing areas and traditional worships (shrines) places [36]. In other areas particularly those under subsistence agriculture and where homesteads are located, the land is held under individualized customary tenure [36].). The crops grown include maize, sorghum, sesame, sunflower and millet. Overall, access to and utilization of land is controlled by male clan heads, sub-clan leaders and elders.

The study employed a mixed method approach what Bekhet and Zauszniewski [37] describe as methodological triangulation -to collect and analyse data of both qualitative and quantitative methodologies.

\subsection{Qualitative methods}

For the qualitative part, ethnographic methods: interviews, focus group discussions and observation, were used to collect data at the different mining villages that are indicated in Fig. 1 . In total, 10 in-depth interviews were held in each district (see Fig. 1). The people who were interviewed included two Senior Environmental Officers, two forestry officers, two district local government (DLGs) chairpersons, two chairpersons of local associations of artisanal miners, and two local politicians in both districts. A further 30 interviews were conducted with artisanal miners including men, women and children, in both Amudat and Moroto districts between 2019 and 2020. In addition, 11 focus group discussions (FGD) comprising of local government officials (3), men (4) and women (4) were conducted in both districts. Local government officials, both men and women, were constituted in one focus group discussions.

However, in some incidents, men and women were organized in separate FGDs to tease out the gender-specific information. The average number of participants in the FGDs was 6 . In other cases, men and women were brought together to validate some of the information obtained from gender-specific FGDs, and gather additional information. A judgmental or purposive approach was used to select the informants for the interviews and FGDs. We selected informants who were involved in mining or held specific leadership positions in the case study districts as they were assumed to have expert knowledge, data and information on the environmental, safety and health impacts of ASM. Further, the observation method was used to collect information on the character, nature, methods of gold extraction from mining pits and how it was

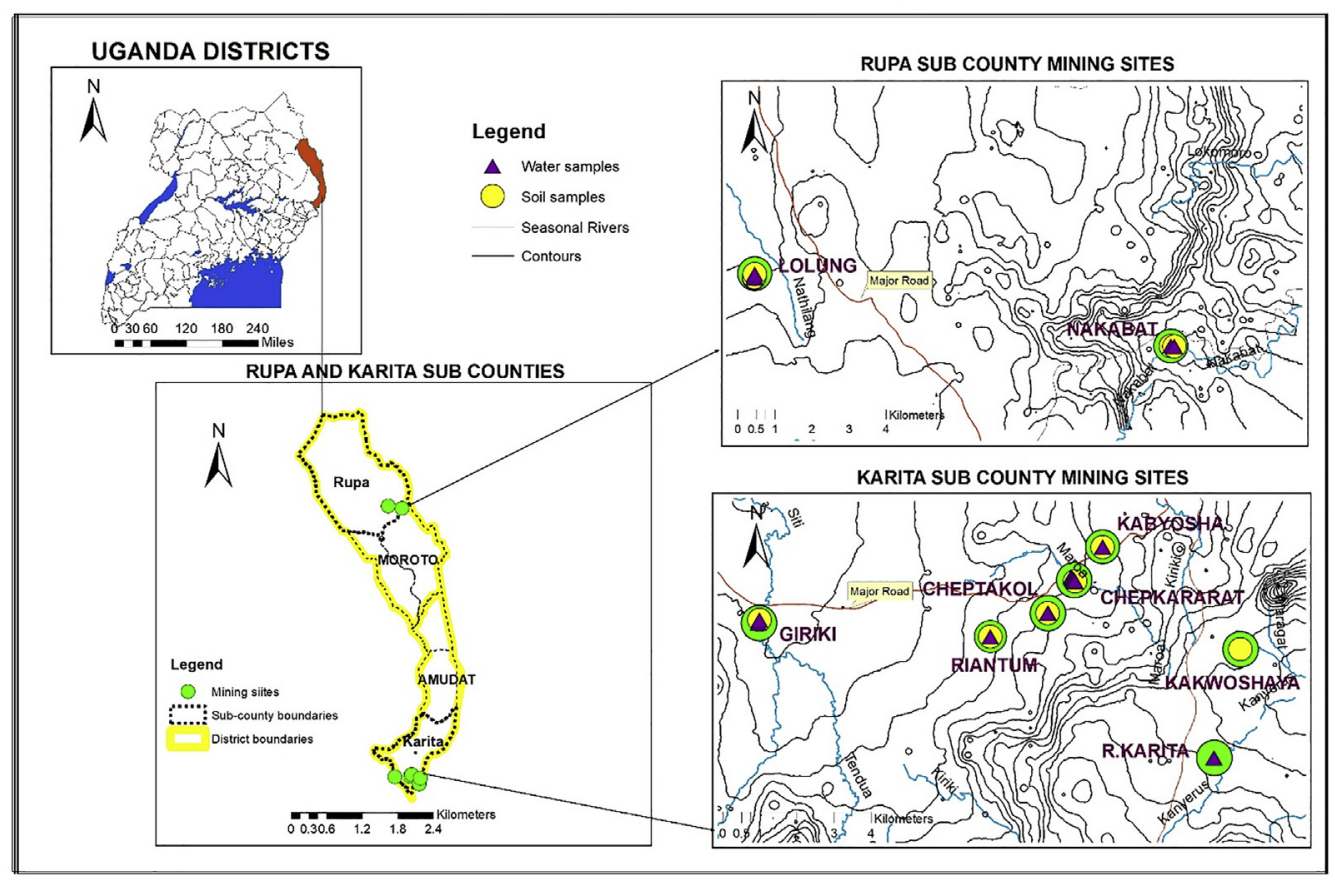

Fig. 1. Mining areas in Moroto and Amudat districts. 
transported to the processing areas. We also observed the gold crushing (either by hand and/or using a ball mill), panning, and washing processes. The principles of good research practice including confidentiality, anonymity and informed consent were followed in the study. In cases where we have mentioned the leadership positions of the informants, we obtained prior permission and consent from the informants to do so.

\subsection{Quantitative approaches}

There are no Occupational Health and Safety (OHS) systems established for Uganda's artisanal mining sector. Miners are exposed to a series of health, safety and environmental risks. To explore this, we collected water samples (12 in the dry season and 14 in the wet season) and soil samples (16 in the dry season and 16 in the wet season) from the artisanal gold mining sites to establish the mercury pollution levels. The soil and water samples were randomly collected from various gold mining areas in the two case study districts (see Fig. 1), stored under ideal conditions and later transported to the Department of Agricultural and Environmental sciences, School of Agricultural sciences, College of Agricultural and environmental Sciences - Makerere University for conducting laboratory testing regarding mercury contamination levels.

\subsubsection{Soil sampling and laboratory testing procedure}

Soil samples collected from the study sites were air dried in the laboratory at about $25^{\circ} \mathrm{C}$ for five days to eliminate the moisture. After drying, they were then ground using a porcelain pestle and mortar and filtered using a $2 \mathrm{~mm}$ sieve to remove debris and other non-soil materials including stones and roots. The sieved soil samples were repackaged, clearly labeled and their chemical composition critically analyzed from the Soil, Plant and Water Analytical Laboratory at Makerere University.

The soil $\mathrm{pH}$ was measured in a soil-water solution at a ratio of 1:2.5 using a $\mathrm{pH}$ meter. Its electrical conductivity was also measured on this same soil water solution using the electrical conductivity meter. For mercury, a known weight of the soil samples $0.50 \mathrm{~g}$ were weighed and placed in a digestion tube and digested using $5 \mathrm{ml}$ of digestion mixture (composed of concentrated sulphuric acid, Hydrogen peroxide, selenium powder and salicylic acid) at $360^{\circ} \mathrm{C}$ and above until a colorless solution was obtained. The compounds in the soil samples were reduced to their corresponding forms after complete oxidation of organic matter. Hydrogen peroxide acts as an anti-foam by oxidizing the organic matter while Selenium powder lowers the boiling point and acts as a catalyst for the process and the concentrated sulphuric acid completes the digestion at elevated temperatures. The digests were cooled, diluted to $50 \mathrm{ml}$ using distilled water and filtered through a Watman filter paper to obtain a clear solution. The concentrations of mercury were determined from the diluent using an atomic absorption spectrophotometer (AAS).

\subsubsection{Water sampling and analysis}

We observed during fieldwork that miners did not put in place any measures to minimize the pollution of the environment by mercury and washing detergents, what is locally known as Omo (see Fig. 5a), were used in the process. Untreated wastewater from washing and panning processes that entailed the use of mercury and other chemicals were directly discharged into the aquatic environment. Thus, we collected the water samples from the streams, rivers and ponds in proximity to gold mining villages. The water samples were filtered through Watman filter papers and the mercury $(\mathrm{Hg})$ was read on the filtrates using the atomic absorption spectrophotometer (AAS). These analytical procedures were performed based on procedures outlined by Ref. [38]. During the digestion and analysis, a reference sample and blanks were repeatedly included for quality control and assurance and hence authenticity of the results. To determine whether there was a significant difference in the mean concentrations of mercury at the selected sites, we run the one-way Analysis of Variance.

\section{Findings}

\subsection{Perceptions of miners on the status, prevalence and extent of mercury use}

Artisanal gold miners in the Karamoja region have relied heavily on rudimentary tools to extract the precious mineral. The mining processes involve excavation of gold-rich lumps of rock and soil from underground pits and brought to the surface for "refining". These rocks are crushed into fine powder [39]. Part of this powder are gold particles so fine that they cannot be seen with the naked eye. The dust is mixed with water in a basin and stirred to form a muddy solution [40]. It is at this stage that mercury is added to the mixture.

The introduction and subsequent use of mercury in gold extraction has increased several folds across the mining sites in the Karamoja region. Today, mercury is considered as a magical invention in that adding a few drops of it in a gold dust solution 
hastens the process of extraction and separation of gold from the soils. This gives miners the opportunity to harvest three times the amount of gold they previously retrieved. A 58-year gold miner who migrated from Tiira gold mines in Busia district to Nakabat in Moroto district, and claimed to have used mercury since the age of nine explained how the use of mercury is key in the mining processes. He claimed that "mercury is the head and the engine in mining. It is the gold. Without mercury, there is no work [mining]" [Interview, 8/08/2020]. Further, he argued that mercury use in gold mining is a "must", meaning that mining is unfeasible without mercury use. Indeed, such claims are corroborated by studies $[17,35,40]$ which argue that mercury is mixed with gold containing materials to form a mercury-gold amalgam which is then heated and vaporized to obtain the gold.

In our study, the prevalence of mercury use is unclear given that we did not undertake a complete survey of all the mines in the case study district. However, the data from interviews, focus group discussions, observation and laboratory analyzes clearly shows that it is unimaginable for any artisanal miner to run a mining operation without the aid of mercury.

"If one is to use half a basin of water for panning and washing, they will need to mix it with just one bottle top of mercury and stir to form an amalgamation. Ordinarily, the main activity for women in the mining sites is to gently agitate sacks of dust to the slow strenuous process of separating dirt from gold. However, like a magnet, mercury effortlessly attracts almost all gold particles in the powder, isolating worthless dirt from the precious metal. The drop of mercury accumulates enough gold to form a tiny silver colored gold ball, the size of a pea" [Interview, 9/08/2020].

\subsection{Mercury pathways and 'transit' routes in Uganda}

The ASGM sector is one of the major drivers behind trade in mercury even when experts warn of the risks that the heavy metal poses not only to human health but also the environment [35]. Mercury that is used in the artisanal mining processes at the selected research sites comes from outside the Karamoja sub-region. We established that mercury trade is a highly secretive activity and that local and global actors underpin the complex geographies of the precious mineral transactions across the country. The mercury distribution networks are closely knit and are often "closed" in nature. Mercury is sold to well-known and trusted dealers and the distribution networks do not easily allow the entry of new traders.

Findings showed that the mercury trade network for ASGM in the Karamoja region was very secretive and suppliers typically only sell it to familiar buyers. One of the gold miners explained the covert nature of mercury trade and the setting where it is sold. "Mercury traders only sell to you if you are known to them" [Interview, 12/08/2020]. Importation of mercury is mainly done by foreign and Ugandan traders of Asian origin as well as nationals from Kenya, Tanzania and the DRC. Trade in mercury is controlled by affluent gold dealers and foreigners with financial capital, connections to the political elite and with links to the global mercury supply chain. Another put it that: "Mercury is sold under and behind the counters of jewelry shops in Kampala's central business district, and in gated households that are mainly owned by Ugandans of Asian origin and people connected to the ruling elite" [Interview, 8/08/2020]. It was apparent that the mercury trading premises were often located in the gated communities that are manned by armed security guards and under the watch of surveillance cameras on a daily basis. Implicitly, it denotes that the mercury trade is not open to ordinary Ugandans but a reserve of a few elites. According to the miners, the most popular mercury trade spot is Kamwokya, an area that lies out of the Kampala's busy business hub.

While Uganda National Environment Management Regulations of 1999 recognize the harmful effects of mercury and provide guidelines for its handling and transportation, mercury oxide is imported into the country unregulated or as a smuggled good [41]. Fig. 2 summarizes the mercury transit routes in Uganda. It was generated based on information provided by miners, laborer and mercury traders. In northern Uganda, ASGM and the use of mercury mainly takes place in Amudat, Nakapiripirit, Moroto, and Kotido districts. In the Eastern Uganda, mining and mercury use is most prevalent in the gold mines of Busia, Bugiri and Namayingo districts. For the central region, the gold mining and mercury use takes place in Mubende district. In the western region, mercury use in gold mining takes place in Kabale and Kisoro districts.

In general, the mercury distribution channels and transit routes can be classified into four categories. Firstly, our interaction with mercury suppliers revealed that the largest source of mercury that is used in Ugandan mines is illegal importation from the Kenyan capital, Nairobi, through Busia, Malaba and other border posts such as Mutukula; on 


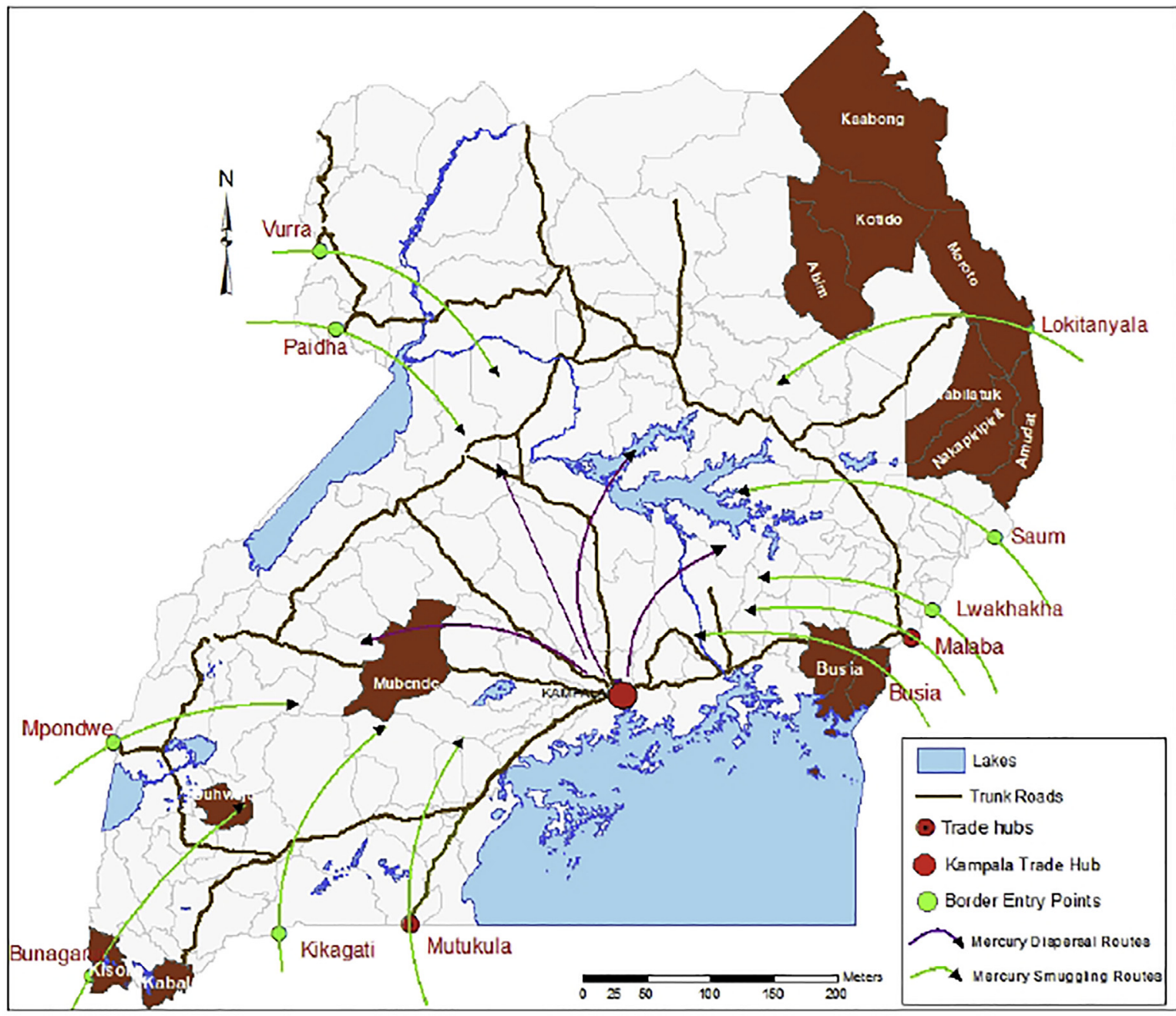

Fig. 2. Mercury transit routes in Uganda.

Uganda-Tanzanian border. Indeed, the United Nations Environment Programme [11] confirms that Kenya and South Africa are the main supply hubs for mercury that is used in the artisanal small-scale gold mines in the Democratic Republic of Congo, Uganda, Tanzania, Zimbabwe, Mozambique and South Africa. A 2016 study by the World Bank reveals that informal in-country mercury trade flows in sub-Saharan Africa have become increasingly evident [42]. Mercury trade statistics indicate that South Africa and Kenya are the principal source countries, although Malaysia appears to have dominated official mercury imports over the past two years. According to the Uganda Revenue Authority (URA), eight consignments totaling $615 \mathrm{~kg}$ entered the country between January 2013 and February 2016, mostly from Kenya, as stated in official records [17]. Uganda's tax body emphasized that smuggling of mercury is likely to be rampant given the apparent lack of logistical and regulatory constraints [43].

While some of the imported mercury is available to Ugandan gold buyers, mercury dealers and artisanal miners at the border points, a significant share is often transported - in a shady manner ${ }^{1}-$ to the distribution points that are located in the central business district of Kampala and other parts of the country. From there, gold miners access mercury through direct purchase or barter trade, or both. A seasoned gold miner (who has engaged in mining in Busia, Tororo, Namayingo, Mubende and Moroto district) explained that "every gold buyer also sells mercury" [Interview, 08/08/2020]. Another miner in Amudat put it that. "When you [a miner] do not

\footnotetext{
${ }^{1}$ Often concealed with other goods and falsefied declaration.
} 
have money, the gold buyers give you the mercury and you pay them later after processing the gold" [Interview, 9/08/2020]. This implies that gold buyers are major mercury distributors and gold trade points are the key mercury distribution hubs. This is consistent with observation made by Kairu [35] who opined that within Uganda, the mercury supply chain is structured in a manner that large-scale informal mercury importers and gold dealers from Kenya, Tanzania and DR Congo have created primary and secondary supply flows under the pretext that it is for industrial, medical use. They have also established links with downstream wholesale and retail mercury dealers consisting of gold brokers and local dealers who then distribute the mercury to the ASGM operators [35].

Secondly, the districts of Moroto and Amudat share their eastern borderline with the Republic of Kenya. Thus, artisanal miners and gold dealers smuggle mercury into Uganda and to the gold mines through the porous and unmonitored border crossing points. An official from Moroto district local government confirmed that "mercury is not sold on the open market because its use is illegal. So, it is smuggled from Kenya to some places in Moroto" [Interview, Environmental Officer for Moroto district, 08/09/2020].

Thirdly, the nature of artisanal mining is such that miners often move from one mine to the other in search of better mining opportunities and outcomes. The Chairman of Artisanal Miners in Moroto district described the pastoral nature of artisanal mining. "We are pastoralists. Gold never moves for you. You have to move for gold. You have to go for it if you want it. You stay put if you do not want" [Interview, 02/04/2019]. Miners from other parts of Uganda where mercury use is widespread often move with mercury to the new mining areas in Karamoja subregion. This is corroborated by the Senior Environmental Officer at Moroto District Local Government who explained, for example, that many of the miners who were evicted by the central government from the Mubende gold mines in Central Uganda moved to Karamoja's Lolung gold mines. Such 'nomadic miners' are also important pathways for the movement of mercury.

Fourthly, Uganda is a transit route for mercury destined for neighbouring mineral-rich countries such as the eastern part of the Democratic Republic of Congo (DRC) where protracted internal instability and displacement has implied that state regulation and control over mercury use are virtually non-existent. However, once the mercury reaches the eastern of part of DRC, much of it is resmuggled back into Uganda and is used in the mining sites in western Uganda and other parts of the country.

Meanwhile, within the Karamoja sub-region itself, mercury trade is controlled by local gold buyers and mercury dealers, mine pit holders and owners of gold concentration and extraction operations. While many of the local gold buyers and mercury dealers are permanently stationed in Kampala and sale the mercury through agents, some directly supply the mercury to the mining sites. Moreover, Chinese mining companies and jewellery shops owned by Asians also trade in mercury. Malaba and Busia border posts on Uganda's eastern border and Mutukula on the Southern border with Tanzania, are the major country's entry points for smuggled mercury. Uganda has also been a transit country for a mercury trade route feeding into the Democratic Republic of Congo (DRC) [17]. However, much of it is smuggled back into the country.

We established that mercury is often sold in kilograms, and that the price of mercury often fluctuated depending on the exchange rate of the United States Dollar. The price also varies with the location. Mercury is sold expensively in Kampala and is less costly in Nairobi. That is why many miners prefer to buy it in Nairobi that Kampala [Interview, 08/08/2020]. Miners and gold traders asserted that the average local price range of a kilogram of mercury was between 350,000 and 500,000 , equivalent to USD 93-133. But because most artisanal miners do not have the financial capacity to buy larger quantities of mercury, local mercury trader often re-packaged the mercury to smaller and affordable portions, often in grams. At the time of the research, the market value of a gram of mercury in mines of Amudat district was between Ugx 1000-2000 (USD 0.3-0.5) [Interview, 08/08/ 2020].

\subsection{Extent of mercury induced soil and water pollution}

Surface and sub-surface mining processes are causing a myriad of ecological problems on land, water, miners and the local communities. Among the most serious environmental problems caused by artisanal mining identified in the case study areas are pollution of soil and water through the discharge of mercury tailings on land, in rivers and streams, and valley floors (see Fig. 3b. Globally, artisanal small-scale gold mining is the largest 


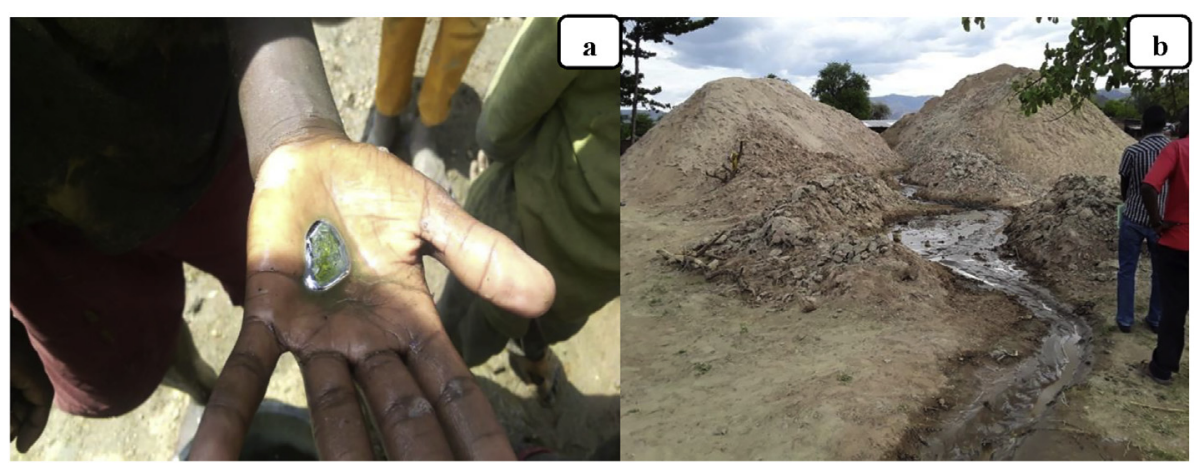

Fig. 3. (a) A child miner holding mercury in his palm in 2019; (b), 'mountains' of mining waste at Girik River washing point in 2020.

single source of mercury pollution as it emits between 410 and 1400 tonnes of mercury each year [44]. "Between 10 and 19 million people use mercury to mine for gold in more than 70 countries" (ibid) and this accounts for $37.7 \%$ of the global mercury pollution. ${ }^{2}$ Estimates indicate that mercury that is released from tailings and vaporisation by burning of the amalgam exceeds 1000 tonnes each year [44].

In Uganda, available information shows that about $32,146 \mathrm{~kg}$ of mercury is released into the environment every year [45]. Out of the above total, gold mining, gold is the highest contributor to these mercury emissions. Out of the above total, gold mining contributes an estimated $18496 \mathrm{~kg}$ of mercury per year. Regionally, the "Central region uses the highest amount of mercury in gold production with over $7800 \mathrm{~kg} \mathrm{Hg} / \mathrm{y}(51 \%)$; followed by the Eastern region with over $5000 \mathrm{~kg} \mathrm{Hg} / \mathrm{y}(33 \%)$ and the Karamoja region uses over $1200 \mathrm{~kg} \mathrm{Hg} / \mathrm{y}$ (8\%)" [45]. Within the Karamoja region, the "mercury hotspot districts are Moroto, Amudat and Nakapiripirit" [45].

As observed in Fig. 3a, (a child miner is seen holding mercury in his palm) the use of mercury is commonplace at most mines in Amudat district. Yet, even in Moroto district where most artisanal miners claimed that they do not use mercury, our findings from the laboratory analysis of water and soil samples from the same area indicate the presence of significant amounts of mercury. Pollution from widespread use of mercury is visible along stream and river banks, such as Girik, in Amudat district. The Chairperson of Okusolota Mining Association in Amudat district attributed the 'green algae' on the banks of river Girik (most of the gold ore is transported to and washed along streams and rivers) to direct discharge of waste that contains mercury into the environment.
Table 1. Mercury $(\mathrm{Hg})$ concentrations in the soils of the different sites in the study area.

\begin{tabular}{llll}
\hline ASGM sites & $\begin{array}{l}\mathrm{Hg}(\mathrm{mg} / \mathrm{kg}) \\
\text { Dry season }\end{array}$ & $\begin{array}{l}\mathrm{Hg}(\mathrm{mg} / \mathrm{kg}) \\
\text { Wet season }\end{array}$ & p-values \\
\hline Cheptakol & 2.61 & 2.88 & 0.06 \\
Kwokwokyaya & 2.70 & 3.00 & \\
& 3.00 & 2.97 & 0.97 \\
Giriki & 1.50 & 1.44 & \\
& 7.50 & 7.41 & 1.00 \\
Nacabat & 7.80 & 7.89 & 0.69 \\
Chepkararati & 2.60 & 2.70 & \\
& 2.90 & 3.00 & 0.86 \\
Kabyosha & 2.05 & 2.16 & 0.07 \\
& 2.78 & 2.88 & \\
Lolung & 4.42 & 4.50 & 0.17 \\
& 4.39 & 4.47 & \\
Riantum & 3.51 & 3.60 & 0.44 \\
& 3.45 & 3.54 & \\
\hline
\end{tabular}

\subsubsection{Mercury $(\mathrm{Hg})$ content in soil from the study sites}

The analysis of soil samples from the case study areas confirmed that mercury is indeed used in the gold mining processes especially in Amudat district. Table 1 shows the concentration of mercury in the soil at the different study sites in Moroto and Amudat districts during the dry and wet seasons. The results reveal that the mercury content ranges from 1.44 to $7.89 \mathrm{mg} / \mathrm{kg}$, with the highest being $7.89 \mathrm{mg} / \mathrm{kg}$ and the lowest at $1.44 \mathrm{mg} / \mathrm{kg}$ as observed in Girik in the wet season and Kwokwokyaya in dry season, respectively. We accept the Null hypothesis, that is to say, there is no difference in means of $\mathrm{Hg}$ Concentration in soil samples collected from the different mining sites in both dry and wet seasons. All the soil samples analysed from the study sites had mercury concentrations above the minimum acceptable limit of $0.03 \mathrm{mg} / \mathrm{kg}$ for total mercury

\footnotetext{
${ }^{2}$ https://www.epa.gov/international-cooperation/mercury-emissions-global-context.
} 
Table 2. Descriptive statistics and ANOVA statistics for the dry season.

\begin{tabular}{|c|c|c|c|c|c|c|c|c|}
\hline & \multirow[t]{2}{*}{$\mathrm{N}$} & \multirow[t]{2}{*}{ Mean } & \multirow[t]{2}{*}{ Std. deviation } & \multirow[t]{2}{*}{ Std. error } & \multicolumn{2}{|c|}{$\begin{array}{l}95 \% \text { Confidence interval for } \\
\text { mean }\end{array}$} & \multirow[t]{2}{*}{ Minimum } & \multirow[t]{2}{*}{ Maximum } \\
\hline & & & & & Lower bound & Upper bound & & \\
\hline Cheptakol & 2 & 2.655 & .06364 & .0450 & 2.083 & 3.2268 & 2.61 & 2.70 \\
\hline Kwokwokyaya & 2 & 2.250 & 1.06066 & .7500 & -7.280 & 11.7797 & 1.50 & 3.00 \\
\hline Girik & 2 & 7.650 & .21213 & .1500 & 5.744 & 9.5559 & 7.50 & 7.80 \\
\hline Nacabat & 2 & 2.750 & .21213 & .1500 & .8441 & 4.6559 & 2.60 & 2.90 \\
\hline Chepkararat & 2 & 2.415 & .51619 & .3650 & -2.223 & 7.0528 & 2.05 & 2.78 \\
\hline Kabyosha & 2 & 4.405 & .02121 & .0150 & 4.214 & 4.5956 & 4.39 & 4.42 \\
\hline Lolung & 2 & 3.480 & .04243 & .0300 & 3.099 & 3.8612 & 3.45 & 3.51 \\
\hline Riantum & 2 & 2.525 & .10607 & .0750 & 1.572 & 3.4780 & 2.45 & 2.60 \\
\hline \multirow[t]{2}{*}{ Total } & 16 & 3.5163 & 1.77974 & .44494 & 2.568 & 4.4646 & 1.50 & 7.80 \\
\hline & & \multicolumn{2}{|c|}{ Sum of squares } & $\underline{\mathrm{df}}$ & Mean square & & F & $\underline{\text { Sig. }}$ \\
\hline \multirow{2}{*}{\multicolumn{2}{|c|}{$\begin{array}{l}\text { Between Groups } \\
\text { Within Groups }\end{array}$}} & \multicolumn{2}{|l|}{46.013} & 7 & 6.573 & & 35.081 & .000 \\
\hline & & \multicolumn{2}{|l|}{1.499} & 8 & .187 & & & \\
\hline Total & & \multicolumn{2}{|l|}{47.512} & 15 & & & & \\
\hline
\end{tabular}

content in soil [46]. The values denote high toxicity of mercury in the soil within and around the selected mining areas in both Moroto and Amudat districts.

In particular, the data analysis in Table 2 shows that the samples from Girik throw the means quite a bit further than the means in other sites for both the dry and wet season. The key question, of course, was whether the difference in mean scores reaches significance. The output of the ANOVA analysis showed that there existed statistically significant differences between the mean concentrations of mercury at the different sites. The value of $F(7,8)$ is 35.081 , which reaches significance with a $p$-value of 0.000 (which is less than the 0.05 alpha level) (Table 2) during the dry season. Meanwhile, during the wet season, the value of $F(7,8)$ is 31.574 , which reaches significance with a $p$-value of 0.000 (which is less than the 0.05 alpha level) (Table 3).

The wider implications of exposure to mercury both in the short and long-term are that it may result into eco-toxicological and human toxicological effects. The eco-toxicological effects of mercury exposure include reduction of the microbiological activity that is important for terrestrial food chains in the soils. Further, plants can easily take up the mercury which increases the chances of indirect human exposure to the mercury through the food chain. The direct human toxicological effects of physical exposure to mercury include the possibilities of "severe neurological disorders and immunedeficiencies even at very low levels of long-term exposure" [46]. In the long-term, mercury can spend between 2 and 3 months in blood, 5-10 months in the liver and 0.5-2 years in the brain [46].

Table 3. Descriptive statistics and ANOVA statistics for the wet season.

\begin{tabular}{|c|c|c|c|c|c|c|c|c|}
\hline & \multirow[t]{2}{*}{$\mathrm{N}$} & \multirow[t]{2}{*}{ Mean } & \multirow[t]{2}{*}{ Std. deviation } & \multirow[t]{2}{*}{ Std. error } & \multicolumn{2}{|c|}{$\begin{array}{l}95 \% \text { Confidence interval for } \\
\text { mean }\end{array}$} & \multirow[t]{2}{*}{ Minimum } & \multirow[t]{2}{*}{ Maximum } \\
\hline & & & & & Lower bound & Upper bound & & \\
\hline Cheptakol & 2 & 2.9400 & .08485 & .0600 & 2.1776 & 3.7024 & 2.88 & 3.00 \\
\hline Kwokwokyaya & 2 & 2.2050 & 1.08187 & .7650 & -7.5152 & 11.9252 & 1.44 & 2.97 \\
\hline Girik & 2 & 7.6500 & .33941 & .2400 & 4.6005 & 10.6995 & 7.41 & 7.89 \\
\hline Nacabat & 2 & 2.8500 & .21213 & .1500 & .9441 & 4.7559 & 2.70 & 3.00 \\
\hline Chepkararat & 2 & 2.5200 & .50912 & .3600 & -2.0542 & 7.0942 & 2.16 & 2.88 \\
\hline Kabyosha & 2 & 4.4850 & .02121 & .0150 & 4.2944 & 4.6756 & 4.47 & 4.50 \\
\hline Lolung & 2 & 3.5700 & .04243 & .0300 & 3.1888 & 3.9512 & 3.54 & 3.60 \\
\hline Riantum & 2 & 2.6250 & .10607 & .0750 & 1.6720 & 3.5780 & 2.55 & 2.70 \\
\hline \multirow[t]{2}{*}{ Total } & 16 & 3.6056 & 1.75320 & .4383 & 2.6714 & 4.5398 & 1.44 & 7.89 \\
\hline & & \multicolumn{2}{|c|}{ Sum of squares } & $\mathrm{df}$ & Mean square & & $\mathrm{F}$ & Sig. \\
\hline \multicolumn{2}{|l|}{ Between groups } & \multicolumn{2}{|l|}{44.495} & 7 & 6.356 & & 31.574 & .000 \\
\hline \multicolumn{2}{|l|}{ Within groups } & \multicolumn{2}{|l|}{1.611} & 8 & .201 & & & \\
\hline \multicolumn{2}{|l|}{ Total } & \multicolumn{2}{|l|}{46.106} & 15 & & & & \\
\hline
\end{tabular}


Table 4. Hg concentration in water for the different sites in Karamoja sub region.

\begin{tabular}{lll}
\hline Season & Site & $\mathrm{Hg}(\mathrm{mg} / \mathrm{l})$ \\
\hline Dry & Nacabat & 1.685 \\
& Karita. R & 0.79 \\
& Cheptakol & BDL \\
& Chepkararati.R & BDL \\
& Kabyosha & BDL \\
Wet & Giriki.R & BDL \\
& Nacabat & BDL \\
& Karita. R & BDL \\
& Cheptakol & BDL \\
& Chepkararati.R & BDL \\
& Kabyosha & BDL \\
& Giriki.R & BDL \\
& Lolung & BDL \\
\hline
\end{tabular}

Note: Detection limit $=0.1 \mathrm{mg} / \mathrm{l}$; BDL, Below Detectable Limit.

\subsubsection{Mercury $(\mathrm{Hg})$ content in water from the study area}

Table 4 shows the results of elemental mercury analysed from the water samples taken from the different sites in the dry and wet seasons. Results indicate that all the sampled sites are characterized with low elemental mercury levels below the detection limit of $0.1 \mathrm{mg} / 1$ for both seasons except for Nacabat and Karita sites in the dry season. For Nacabat and Karita site, mercury concentrations were $1.69 \mathrm{mg} / 1$ and $0.79 \mathrm{mg} / \mathrm{l}$, respectively.

Mercury concentrations in the water samples are above the established water quality guidelines for mercury, including the $0.002 \mathrm{mg} / \mathrm{l}$ drinking water mercury guideline recommended by the United Nations Environmental Protection Agency [47]. In addition, the mercury levels in water samples from both sites were above the $0.006 \mathrm{mg} / 1$ international drinking water mercury threshold recommended by the World Health Organization [48]. High mercury concentration in waters creates risks for human health. Moreover, the risks are amplified when mercury contaminates the aquatic environment as significant local contamination often results in elevated levels of exposure in people. Human exposure to mercury in water can cause multiple toxic effects including damage to the cardiovascular system, nephrotoxicity, abdominal pain to tremor and paralysis. Therefore, measures from the Minamata Convention including environmental and food monitoring should be conducted in Karamoja to counteract the negative impacts of accumulated mercury in soil and water.

Although most mercury pollution levels in water were below detectable levels, there are noticeable impacts within and around the mines. First, women and children whose main activity in mines is panning and washing of gold reported severe skin irritation, with some getting "permanent" skin disorders. The Chairperson of Amudat District Local government argued that "women and children are the most affected as they directly step in mercurycontaminated gold washing ponds and use bare hands to wash the gold" [Interview, 2/04/2019]. We observed that most children and women miners had developed cracks on their feet and hands (as they directly step in and use bare hands to pan and wash a mix of gold and mercury).

While in the field, we came across a group of women washing and panning gold the Chepkararat bridge. On close interaction, the women claimed that they do not use mercury in the washing and panning processes. Yet, many often observe smaller mercury particles at the bottom of their pans and/or basins after every panning session. They argued that the mercury that they often find at the river bed comes from the mining sites in the upper catchments of river Chepkarat. Mercury seeps through the riverbed to the lower sections of the river and disperses to the different sections of the catchment [Interview and observation 2/04/2019]. We took water samples at different points of Chepkarart river. As indicated earlier, we took random water samples from the river Chepkararat and tested them for mercury. All the water samples tested positive for mercury, with the pollution levels exceeding internationally accepted standards.

Studies elsewhere indeed confirm that exposure to high mercury levels, similar to the one seen in Fig. 3, can have adverse impacts on people including itching and skin irritation, a health condition referred to as Dermatitis [13]. Available evidence further shows that mercury can be absorbed through the skin to the human body "across the epidermis and via the sweat glands, sebaceous glands, and hair follicles" [49]. This means that mercury that is used in panning and washing finds its way into the bodies of women and children who mainly engage in these activities. For children, the risks of mercury exposure are substantial as it could result in "physical and mental disabilities and compromised development" [44]. This corroborates the findings from a recent study that found high levels of mercury in urine and blood samples from artisanal miners in the four regions of Uganda including the Karamoja region [13]. Given that exposure to mercury damages the "brain and kidney" [49], it denotes that mining could put the lives of artisanal miners at risk with long and short-term consequences not only for them alone but even those living around the mining villages.

The streams, rivers and other water bodies across Amudat and Moroto districts also evidenced heavy 
levels of pollution emanating from the use of mercury.

The population that lives close to water bodies and marine ecosystems where mining takes place in the study areas is more at risk as increased utilisation of water from polluted sources accentuates the risks of mercury exposure beyond safe limits. This appears to be the case in the mining villages where the local communities depend on the streams and rivers for water as there is no piped water supply. Essentially, the possibility for mercury to affect the wider population, including children and pregnant women, is high given these circumstances. Exposure of pregnant women and their unborn children to mercury 'has been associated with cognitive impairment, as well as decrements in memory, attention, fine motor skills, and other markers of delayed neurodevelopment' [50]. For the rest of the population, mercury could lead to cardiovascular diseases and cognitive impairments [51].

\subsection{Mercury use in refining gold and direct health related effects}

The final stage of the gold mining process involves the heating of the amalgam over a candle wax, firewood or using gas to further separate the mercury from the gold. According to the miners, three grams of mercury are used to produce one gram of gold. The gold ball is then placed on a spoon and burnt using a gas-powered burner to remove any remaining mercury impurities and the output is an even smaller ball of pure gold. This is possibly one of the deadliest stages because the fumes released from the burning process are inhaled by the entire camp [40].

Global estimates indicate that mercury released from heating mercury-gold amalgams every year is in excess of 1000 tonnes [13]. Mercury in vapor form has dire and fatal consequences for the miners. Studies indicate that elemental mercury is easily taken up by the lungs and that approximately
$74-80 \%$ of the inhaled mercury is retained in the human body [52]. The inhaled mercury affects various parts of the human body including the red blood cells, the kidney and the nervous system [53]. Mercury accumulates in the kidney, liver, skin and lungs causing permanent illnesses and a range of other impairments. Once Mercury reaches the lungs it destroys the covering of the nerves and enters the blood stream [40]. Studies elsewhere have also associated human exposure to mercury with emotional instability, insomnia, neuromuscular problems, infertility, headaches and a host of other sicknesses [54,55]. Besides, the environment and fragile systems within and around the mining villages are also affected by elemental mercury through, air water and soil pollution.

These existential challenges as faced by artisanal gold miners are exemplified by the submission of a labourer in one of the local mines in Moroto district:

"For several years now, I have to toil in the river valley on a daily basis searching for gold. Can't you observe that I have my little children with me right now, despite my health condition? Everywhere, hundreds of local residents including children and women are ubiquitously searching for gold. Just like many other women miners that you see around, I have developed chest pains and coughing incessantly, we can't undertake appropriate agricultural activities including crop growing and that means, we can't easily quit this activity for lack of alternative sources of income. We are also aware that exposure to mercury can be passed from a mother to her unborn child. Many women have been diagnosed with several ailments, and we cannot tell whether this is a result of mercury use. We have been advised over and over again that our ailments arose out of inhaling dust and mercury vapor but we haven't received any other help yet" [Interview, 10/08/2020].

The washing of gold ore along the shores of rivers, streams and other water bodies is invariably affecting the water sources, fragile ecosystems and

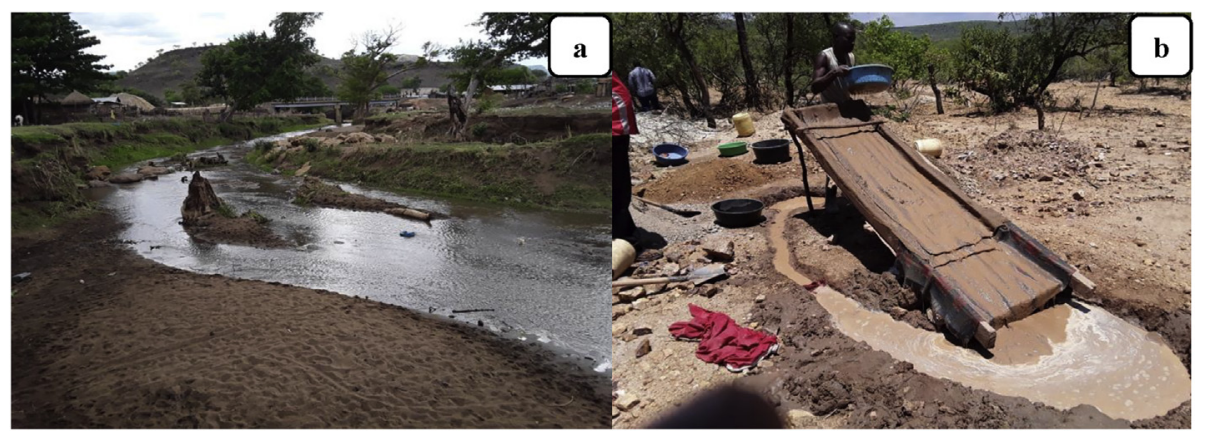

Fig. 4. (a) Polluted Girik river in Amudat district in 2020, (b) water pollution at Karita mining site in 2019. 
the local communities that live within and close to the mining villages. Piles of waste rock, earth and sand have ended up polluting water ground and underground water sources, precipitating soil erosion and siltation of rivers, streams and other water bodies (see Fig. 4). The local communities that live along and utilise the water from these water bodies claimed that washing of gold-containing soils along the river banks has affected the water quality [Interview, 2/04/2019. In Amudat district, there were complaints of increased turbidity of the water from Girik river. This was attributed the dirtiness of the water to increased intensity of gold washing and panning along the river. Many community members at Girik town complained of skin infections among children, an issue they associated to playing in the dirty water of Girik river.

We observed that livestock - Karamoja is a pastoral community with cattle, goats and sheep - in the mining communities often drink the mercury contaminated water in the abandoned washing and panning ponds (see Fig. 5). Wildlife and livestock in areas where mercury-contaminated ponds abound is likely to increase the possibilities of the mercury finding its way in the food chain especially given that wild game in Karamoja is a major source of animal products (such as milk and beef) for many parts of Eastern and central Uganda. Moreover, some of the mining sites such as Lolung in Moroto district are located in wildlife reserves. It is more common for the wildlife to be exposed to water that has been contaminated with mercury in the drier periods when the water is scarce. Moreover, some of the miners especially in the wildlife reserve hunted down some of the wild game for human consumption [Interview, Environmental Officer for Moroto district, 8/08/2020]. It is also evident that some of the mercury in the ponds ultimately evaporates in the air and some of it dissolves in the soil, with greater implications on ground and underground water sources and land.
The waste materials from panning and washing processes often contain mercury tailings much of which ends up in rivers and streams. Given that open water sources are the major sources of water for the communities, it means that most people use water that is contaminated with mercury. The ultimate results are that the mercury ends up in the food chain and people's bodies [49]. This resonates with related studies that have revealed that most of the people at most artisanal mining sites in Uganda have high levels of mercury in their bodies [13].

Reports elsewhere indicate that mercury poses other grave health effects for miners. Kairu [35] reports that because miners have to work for long hours while panning soil, their eyes are strained to distinguish gold fragments as tiny as grains of sand from soil texture and later into one solid piece. This has resulted in escalating cases of eye problems among those staying in or around villages where mining is intense. Human exposure to mercury can cause dizziness, fatigue, general body weakness, depression, shaking of hands and memory impairment [13]. In other cases, it causes chest pain, corrosion of the mucus membrane and gastrointestinal tract, and mercurial stomatitis [49].

In addition, the mining processes cause noise and air pollution. The equipment that is used in mining: generators that provided power to the mines, ball mills for crushing the gold-containing rocks to fine powder, and trucks that were used to transport the gold more to the washing and panning sites, were key sauces of noise and air pollution within the mining communities. More worrying is that the sand from mining activities, where mercury has been used, is subsequently utilised in house construction. "The sand from mining is sold to people who intend to construct houses" [Interview, 10/08/ 2020]. Although we were not able to identify the immediate and long-term impacts of using mercury contaminated sand for the construction of houses, it appears that this causes in-door air pollution. Since
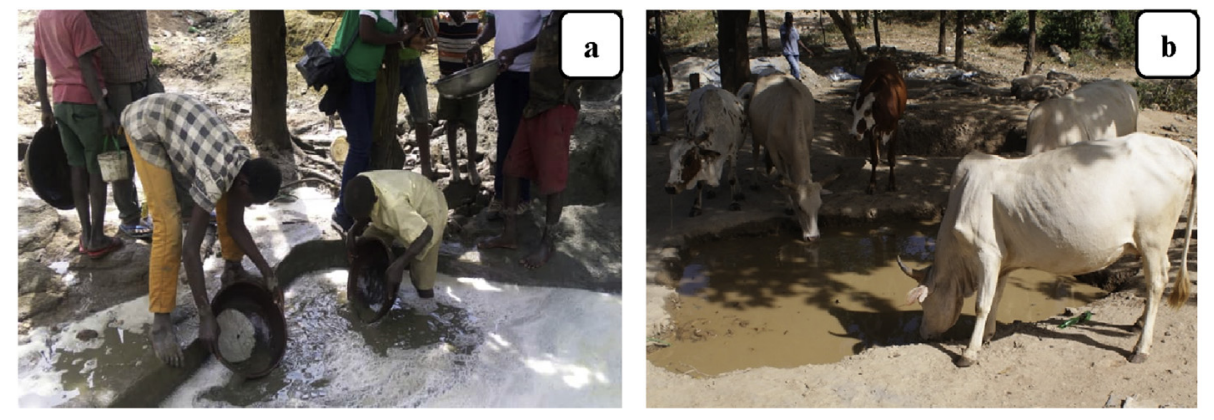

Fig. 5. Children washing/panning gold in mercury contaminated water in 2019, (b), cows drinking mercury contaminated water in an abandoned panning/washing pond in 2019. 
pollution in closed environments is often higher than that which takes place outside of buildings, the impacts could be greater for people: men, women and children, that occupy the houses.

\subsection{Environmental and landscape changes}

Changes in the components of the environment are observed as a result of mining activities in Karamoja region. Gold mining techniques take two forms. The first is open surface/alluvial mining that does not require any deeper excavation. It is carried out by local men, women and children on open land, stream and river valley beds and involves the use of basic tools, such as basins, to pan and wash loose earth materials. Working conditions in surface mining are less dangerous for miners and this attract a large number of women miners too. It essentially requires the removal of earth and rocky materials covering the gold deposits. The second technique is sub-surface or underground mining. Often carried out by the relatively affluent miners with more sophisticated equipment such as the makta, ball mills, compressors, and electric generators. Sub-surface mining entails the opening up of pit and tunnels to extract the gold that is deposited in layers/lines - locally referred to as veins - that often run though the underground rocks.

The two forms of mining are invariably affecting the fragile ecosystems in both Amudat and Moroto districts and a number of related environmental and safety challenges including land surface deformations deforestation and land change are prevalent.

\subsubsection{Land clearances and change}

Mining processes have indirectly resulted in high rates of deforestation and loss of landcover in the study areas. While the mining communities in Karita sub county put the deforestation rate and land cover loss at $24 \%$, those in Rupa sub county put it at $29 \%$. Miners have cleared large swathes of land as they explore the potential areas with viable gold deposits and as they ready the new sites for mineral extraction. The Environment Officer for Moroto district explained that "miners often cut down trees as they follow the gold bearing veins (Fig. 6). This is because gold deposits have a systematic formation. It is deposited in layers called veins. If the tree is in the gold line, then it is often cut down" [Interview, Environmental Officer for Moroto district, 8/08/2020]. Sub-surface mining activities particularly the tunnels have resulted in the loss of trees as the tunnels often destabilise the soils. While some of the trees finally dry up, others end up falling due to the instability caused by the mining tunnels. We observed at all mining villages that most gold exploration processes are done in a rudimentary manner using local knowledge and through guesswork. This has contributed to land cover loss in Amudat district where miners have cleared trees other natural vegetation for mining purposes. In Moroto district, "some of the tunnels have been dug under roads. This has compromised the structural integrity of the road surface in the affected areas, posing serious safety challenges for the users and the general community" [Interview, Environmental Officer for Moroto district, 8/ 08/2020].

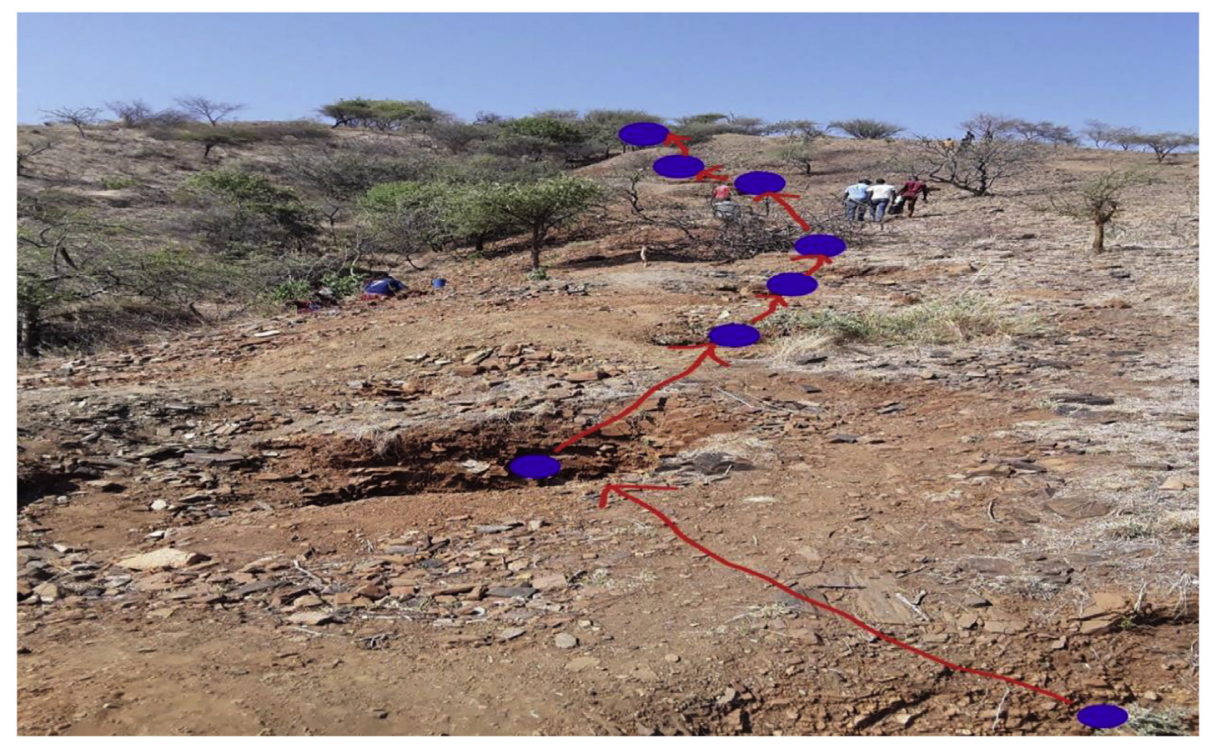

Fig. 6. Mining pits aligned along a gold bearing vein or rock formation at Nakabat mining site in 2019. 
Rampant land clearance is often accentuated when mining is at a low ebb as miners have to devise other livelihood and survival options. During such times, the alternative for some miners is to engage in the sale of firewood and charcoal burning. The Forest Officer for Moroto District Local Government explained "miners sometimes engage in charcoal business. Others burn charcoal for sale. But they also cook, so they cut down trees for firewood" [Interview, 8/08/2020]. In other cases, miners require the firewood to fire and loosen the gold-containing rocks. "Sometimes, miners harvest firewood to fire the rocks so that they can be split with ease" [Interview, 8/08/2020]. This was corroborated by observations at Riatum mines where smoke was seen coming out of the mining pits. On further inquiry, the miners claimed that they were trying to loosen the rocks that were hard to break.

Meanwhile, other miners engage in the harvesting and sale of Aloe vera. The plant is a major constituent element of the natural environment in Karamoja. So, its exploitation in vast quantities is significantly impacting on landcover in the region. The environmental officer for Mororo district explained that some of the miners harvest aloe vera particularly during the dry spell when there are limited activities at the mines due to scarcity of water [Interview, 8/ 08/2020]. This was the case for Nalongo - a woman miner at Nakabat gold mines in Rupa sub-county who explained how she often switched between mining and harvesting of Aloe vera. "I used to harvest Kyigaji [Aloe Vera] in the day and engage in gold dealing in the night. That is how I was able to make ends meet" [Interview, 8/08/2020]. Overall, as illustrated above, artisanal gold mining activities are invariably contributing to the modification of the natural environment in form of deforestation and natural land cover loss.

\subsubsection{Land surface deformations}

Two specific land surface deformations associated with gold mining at the mining sites included generation of huge piles of mining waste materials and widespread presence of open mining pits.

As seen in Fig. 7, gold mining is gradually transforming the typically rural Karamoja landscape as it has resulted in the deposition of piles of waste rock and sand. In some cases, tonnes of waste sand and rocks are merely abandoned at the panning and washing points after extraction of the gold. In other cases, the gold ore is not washed and panned at the point of extraction because of limitations of water (Karamoja is a semi-arid area) - a key input in gold panning and washing processes. Instead, gold ore is loaded on trucks and transported to where water bodies such as streams and rivers are located. It is here that the washing of gold-containing soils takes place. We observed that this practice was more prevalent in Amudat district where truckloads of gold-containing rocks from Chepkararat, Karita and other mines are transported to Girik town. The gold ore is washed in Girk river.

At all the mining sites visited during fieldwork, we observed that miners had left behind open mining pits of varying shapes, sizes and depth. The mining pits have given rise to other impacts in the mining villages including alteration of the landscape in Karamoja. After exhaustion of the gold, the miners simply abandon the old pits and open up new ones without any initiatives to cover and reinstate the environment to its original and pre-mining state. The abandoned mining pits had become breeding grounds for disease-causing vectors such as mosquitoes. The open pits store stagnant rain water thereby providing ideal conditions for the breeding of mosquitoes.

The deepest mining pit, found at Lolung mines in Rupa Sub-county, was about 120 feet. In other mines, such as Riantum, miners opened up mining tunnels as they followed the gold-bearing veins. The miners at Riantun mines claimed that some of the tunnels were opened up in the 1970, and until now the mining areas have not regenerated. Some of the abandoned mining tunnels are up to a depth of

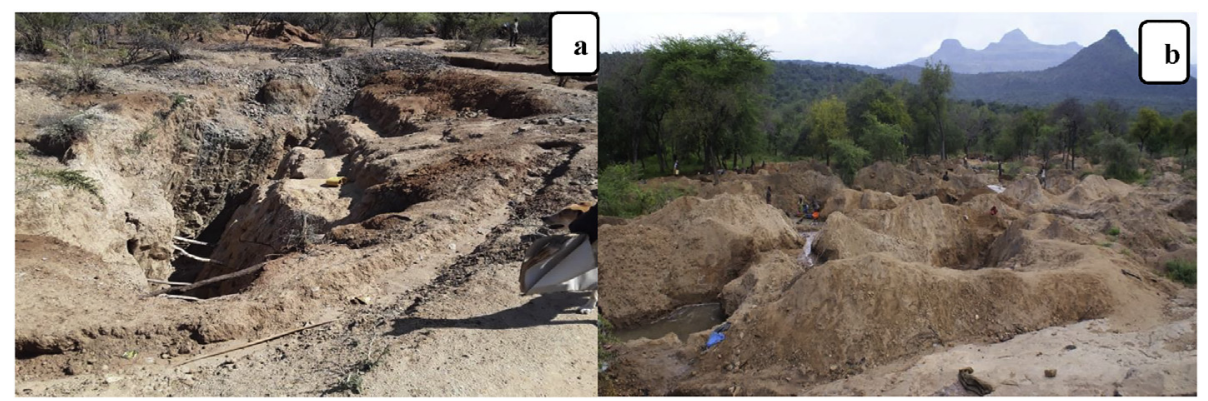

Fig. 7. An abandoned gold mining pit at Lolung in 2019; (b), Active gold mining pits at Kabiosha mines in 2020. 
60-100 feet and no attempts have been made to cover them once the gold-bearing ore were exhausted. Pit collapses arising out of subsidence and rapid displacements and falls of blocks of rocks and earth materials were reported as routine occurrences at the mining sites. Many of the abandoned mining pits have become a major source of mining accidents to people, wildlife and livestock. These pits have essentially turned into death traps as many lives have been lost due to miners being buried after the pits caved in. Moreover, miners often construct makeshift ponds from where gold is panned and washed. However, many of the ponds at the decommissioned mining sites have also merely been abandoned with no initiatives taken, both short and long term, to cover them.

The Senior Environment Officer for Amudat District Local Government explained that miners and the local government have not been able to either backfill and cover the pits or restore the landscape to its original state because of the associated high costs that are required to do so. For Moroto district, the Environmental Officer argued that "environmental restoration has been very difficult because the local communities think that we [people] don't nurture nature. Local people think that trees do not need any attention. The local government gives them trees to plant but our efforts go to waste as people do not plant and others do not take care of them" [Interview, Environmental Officer for Moroto district, 8/08/2020].

The local communities reported that the collapsing of mining pits was the major cause of fatalities at the mines, with estimates of over $90 \%$ for Rupa subcounty and $98 \%$ for Karita sub-county. At least 5 miners die each year at the Nakabat mining site in Rupa sub county, while at least two people die each year in other mining sites in Karita sub county. We observed in both districts that none of the miners had any personal protective equipment (gloves, helmet, boots, face masks and safety glasses) during the mining processes.

\subsection{Other personal safety and health risks associated with mining}

Apart from the safety risks associated with the open mining pits, it was observed at most of the mining pits that at an individual level, most miners did not have any personal protective equipment such as gloves, helmet, boots, face masks and safety glasses. Many used bare hands to undertake various activities at the mining sites. The safety issues were explained by the Environment Officer of Moroto district:
"Mining pits have claimed many miners especially those who do not have protective gear. They are just death traps and for youths who absent themselves from school to look for quick money, no effort, on their part, is made to procure safety and protective gear" [Interview, 03/04/2020].

In a narrative epitomised by the quote "I am still searching for my leg", Adyaka, the Deputy Chairperson of Amudat District Local government at the time of conducting fieldwork in 2019 explained how mining adversely changed her life as it brought lifetime impairments. At the age of 10 in 1994, Adyaka, fell in a mining pit, an accident that left her disabled in both limbs and significantly reduced the functioning of her hands. She recounted in an interview:

"I suffered several fractures especially with my legs. I also had a broken hand. One of my friends broke her ribs and jaw, and she lost most of her teeth. I was carried on an improvised stretcher back home. After three days, I was taken to a local hospital but the doctors there could not manage my condition. So, I was referred to Kapenguria hospital in Kenya. Later when I joined the mission school, I was taken for another operation at Kajado hospital in Kenya" [Interview, 04/04/2020]. Although the accident was not fatal, the multiple fractures, permanent impairments and life's challenges faced by Adyaka are a constant reminder of the implications of gold mining on communities living in and around the mining villages. Adyaka explained that people in her village and at Kampala University where she attained university education often laughed at her because of the disabilities. She further claimed that at the time of delivery of her first child, the doctors did not give her any chance to deliver normally because of the pre-conceived idea that people like her cannot have normal delivery.

"When doctors see that one is disabled, they know that it is an automatic caesarean case even without conducting the necessary observations and tests checking whether one can or cannot deliver normally. They often say, she's disabled and that is a caesarean case" [Interview, 04/04/2020].

Moreover, Adyaka attributed the rejection she has received from her husband, peers and the community to the physical impairments she suffered due to the accident. She explains how she was rejected by her husband and his relatives:

"The person who made me pregnant started to say that he has married a lame person. His relatives often said that he married someone who moves like a snake. Later-on, he said; ohh its true! I have married a disabled woman. He separated with me in 2011-2013" [Interview, 04/04/2020]. 
Although there are differences in the gravity of the mining accidents, Adyaka's experiences are similar to many other members of the local communities and miners who reported several forms of disabilities and various forms of impairments sustained at the mines. These incidences point to the adverse impacts of uncovered mining pits to the local communities in the mining villages and the need to regularly cover and restore the environment to its original state after decommissioning of the mines. In earlier media reports by Ongode [40], the trapping of miners under the ground was seen as one of the health and safety issues associated with gold mining in Uganda. Moreover, respiratory problems caused by continuous inhalation of dust and the occasional collapse of tunnels were prevalent given that the miners use rudimentary techniques to extract as much gold as they could.

\section{Conclusions}

Although ASM contributes to social and economic development of the mining communities in the Karamoja sub-region, it also causes multiple environmental, health and safety problems to the miners and broader mining villages. While the impacts of localised ASGM processes could be minimal at each mining site, the aggregate and cumulative impacts from all the artisanal mines in both districts could cause greater impacts for the region. Pollution does not respect borders. Localised and mine-specific environmental, health and safety concerns could have wider and intricate implications beyond the specific mining sites and villages. This appears to be the case in the mines of Amudat and Moroto districts where available information reveals widespread transformation in the fragile ecosystems within the mining sites and beyond.

Extensive mercury use in the ASGM of Karamoja has caused adverse impacts on land, air, ground and underground water systems. We established that sophisticated multi-actor cartel-like structures underpin the trade and marketing of the mercury in Uganda. Trade in mercury is highly secretive, with most of it brought into the country, largely from Kenya and South Africa and particularly by foreign nationals, through mis-declaration, bribery/corruption and smuggling across Uganda's porous borderline. In-country mercury trade network are also complicated: it is sold behind counters and in gated communities in Uganda's capital but only to trusted buyers. Laboratory analysis of water and soil samples revealed the presence of significantly higher amounts of mercury in both Amudat and Moroto districts. Most of the water and soil samples exhibited pollution levels that exceed internationally accepted standards. Other noticeable impacts of ASGM included green algae along streams and river banks, uncovered mining pit, huge piles of mining waste, and unregulated clearance of landcover.

Although mercury use in mining is prohibited by the government in light of its adverse environmental and health dangers it poses to the miners and the broader mining communities, there is no specific and detailed law(s) to regulate its use in Uganda. The Mining Policy of 2001, the Mining Act of 2003 and the Mining Regulations of 2004 are silent on the use of mercury. We suggest that this loophole should be plugged by formulating a specific law(s) which specifically underline the conditions under which mercury can and cannot be traded and used. The penalties for those who contravene the law(s) and regulation(s) should also be stipulated. Moreover, most of the informants were ignorant of the impacts of mercury use on their lives and the local communities. A key informant asked: "Why do you tell me that mercury use in mining is bad when I have never seen anything wrong with its use? I have used mercury since childhood, and throughout my mining life, but have never suffered from any illness related to mercury" [Interview, 08/08/2020]. On this basis, we propose that the Ugandan government and the district local governments sensitize the miners and all the people in the mining villages on the dangers of mercury use on people's health, the environment and broader communities. The leaders of Amudat District local government proposed that there is need to have clear interventions that are aimed at empowering the local communities that are involved in artisanal gold mining. "We need to package the interventions well by empowering the miners and provision of alternative mining methods and livelihoods" [FGD, 11/12/ 2018]. Moving forward, we recommend that the ban on mercury use in mining should be strictly enforced, alternative methods of gold processing availed to the miners, and that environmental restoration be undertaken by the miners in close collaboration with the district authorities.

\section{Ethical statement}

The authors state that the research was conducted according to ethical standards.

\section{Funding body}

The research benefitted from the generous funding provided by the Carnegie Corporation of New York, United States of America through 'Nurturing Emerging Research Leaders through Post-Doctoral 


at Training Project (NERLP) at Makerere
University'.

\section{Conflicts of interest}

None declared.

\section{Acknowledgments}

We appreciate the contributions of the local communities and artisanal miners in the gold mining villages of Moroto and Amudat districts, and staff at Moroto and Amudat district local governments. Gratitude also goes to the Senior Environmental Officer for Amudat District Local government, Research Assistants, translators and anonymous reviewers for the insightful comments.

\section{References}

[1] Veiga MM, Hinton JJ. Abandoned artisanal gold mines in the Brazilian Amazon: a legacy of mercury pollution. Nat Resour Forum 2002;26(1):15-26.

[2] Ledwaba PF. The status of artisanal and small-scale mining sector in South Africa: tracking progress. In: Journal of the Southern African Institute of Mining and Metallurgy. South African Institute of Mining and Metallurgy; 2017. p. 33-40.

[3] Tschakert P, Singha K. Contaminated identities: mercury and marginalization in Ghana's artisanal mining sector. Geoforum 2007;38(6):1304-21.

[4] de Soto $H$. The mystery of capital: why capitalism triumphs in the West and fails everywhere else. New York: Basic Books; 2000.

[5] Levin E. Artisanal and small-scale mining [Internet]. 2004. Available from: https://www.worldbank.org/en/topic/ extractiveindustries/brief/artisanal-and-small-scale-mining.

[6] World Bank. State of the artisanal and small-scale mining sector acknowledgments and key contributors [Internet]. Washington, D.C. 2019. Available from: https://www. pactworld.org/download/4210/nojs/Delve-2019-State-of-theArtisanal-and-Small-Scale-Mining-Sector.pdf.

[7] Maconachie R, Hilson G. Artisanal gold mining: a new frontier in post-conflict Sierra Leone? J Dev Stud 2011;47(4): 595-616.

[8] Smith NM, Ali S, Bofinger C, Collins N. Human health and safety in artisanal and small-scale mining: an integrated approach to risk mitigation. J Clean Prod 2016;129:43-52.

[9] Banchirigah S, Hilson G. De-agrarianization, re-agrarianization and local economic development: Re-orientating livelihoods in African artisanal mining communities. Pol Sci 2010;43(2):157-80.

[10] Mwesigye R. Uganda to adopt Tanzania ASM model.. Oil in Uganda [Internet]; 2020. Available from: https://oilinuganda. $\mathrm{org} / \mathrm{mining} /$ uganda-to-adopt-tanzania-asm-model/.

[11] UNEP (United Nations Environment Programme (UNEP)). Analysis of formalization approaches in the artisanal and small-scale gold mining sector based on experiences in Ecuador, Mongolia, Peru, Tanzania and Uganda: Tanzania case study [Internet]. Geneva, Switzerland. 2012. Available from: https://wedocs.unep.org/bitstream/handle/20.500. 11822/11357/Formalization_Document_Final_June_2012.pdf? sequence $=1$ \&is Allowed $=\mathrm{y}$.

[12] Musiime CB. Expecting Eldorado? An Analysis of Uganda's Expectations of their Country's Oil Wealth. In: Langer A, Ukiwo U, Mbabazi P, editors. Oil Wealth and Development in Uganda and Beyond: Prospects, Opportunities and
Challenges. Chapter 12. Leuven University Press; 2020. p. 265-84. https://www.jstor.org/stable/j.ctvt9k690.18.

[13] Wanyana MW, Agaba FE, Sekimpi DK, Mukasa VN, Kamese GN, Douglas N, et al. Mercury exposure among artisanal and small-scale gold miners in four regions in Uganda. J Heal Pollut 2020;10(26).

[14] Hinton J, Kabongo I, Kabiswa C, Okedi J, Mbabazi R. The mining and minerals sector in Karamoja region. Baseline Assessment of the mining and minerals sector in Karamoja, Uganda [Internet]. Kampala, Uganda. 2011. Available from: https://thisisafrica.files.wordpress.com/2011/12/miningsector-report-karamoja-region.pdf.

[15] Hentschel T, Hruschka F, Priester M. Global report on artisanal and small-scale mining, minerals mining and sustainable development (MMSD) Project [Internet]. London. 2002. Available from: https://pubs.iied.org/pdfs/G00723.pdf.

[16] Nabaasa H. Artisanal and small-scale gold mining and food security: an ecological perspective. African J Public Aff [Internet] 2016;9(4):144-55. Available from: https:// repository.up.ac.za/bitstream/handle/2263/59020/Nabaasa_ Artisanal_2016.pdf? sequence $=1$.

[17] Waiswa B. Mercury continues to eat into health of gold miners. Earthfinds [Internet]; 2019 Aug. Available from: http://earthfinds.co.ug/index.php/mining/item/2464mercury-continues-to-eat-into-health-of-gold-miners.

[18] Barasa B, Kakembo V, Karl T. Characterization of artisanal gold mining activities in the tropics and their impact on sediment loading and stream flow in the Okame River catchment, Eastern Uganda. Environ Earth Sci 2016;75(14): $1-13$.

[19] Mpagi I, Ssamula NF, Ongode B, Henderson S, Robinah HG. Artisanal gold mining: both a woman's and a man's world. A Uganda case study. Gend Dev 2017;25(3):471-87.

[20] Siu G, Wight D, Seeley J. How a masculine work ethic and economic circumstances affect uptake of HIV treatment: experiences of men from an artisanal gold mining community in rural eastern Uganda. J Int AIDS Soc 2012;15:17368.

[21] Akumu P, Kelly A. Silence far from golden for child labourers in the mines of Uganda. The Guardian [Internet]; 2016 May 20. Available from: https://www.theguardian.com/ global-development/2016/may/20/child-labour-ugandagold-mines-silence-far-from-golden.

[22] Sinding K. The dynamics of artisanal and small-scale mining reform. Nat Resour Forum 2005.

[23] Edwards DP, Sloan S, Weng L, Dirks P, Sayer J, Laurance WF. Mining and the African environment. Conserv Lett 2014;7(3):302-11.

[24] Burke G. Opportunities for environmental management in the mining sector in Asia. J Environ Dev 2006;15(2):224-35.

[25] Bagah D, Angko W, Tanyeh J. Environmental degradation and small scale mining nexus: emerging trends and challenges in northern Ghana. Dev Ctry Stud 2016;6(2):38-45.

[26] Kambani SM. Small-scale mining and cleaner production issues in Zambia. J Clean Prod 2003;11(2):141-6.

[27] Van Straaten P. Mercury contamination associated with small-scale gold mining in Tanzania and Zimbabwe. Sci Total Environ 2000;259(1-3):105-13.

[28] Mol JH, Ouboter PE. Downstream effects of erosion from small-scale gold mining on the instream habitat and fish community of a small neotropical rainforest stream. Conserv Biol 2004;18(1):201-14.

[29] Heemskerk M. Livelihood decision making and environmental degradation: small-scale gold mining in the Suriname Amazon. Soc Nat Resour 2002;15(4):327-44.

[30] Cremers L, Kolen J, Theije M. Small-scale gold mining in the Amazon. In: Cuadernos del CEDLA; 2013.

[31] Leung AMR, Lu JLDP. Environmental health and safety hazards of indigenous small-scale gold mining using cyanidation in the Philippines. Environ Health Insights 2016;10. EHI-S38459.

[32] Kouankap NGD, Tah BC, Wotchoko P, Magha A, Chianebeng JK, Tene DJF. Artisanal gold mining in Batouri 
area, East Cameroon: impacts on the mining population and their environment. J Geol Min Res 2017;9(1):1-8.

[33] Ako T, U. O, S. O, Adamu I, Ali S, Mamodu A, et al. Environmental impact of artisanal gold mining in Luku, Minna, Niger state, north Central Nigeria. J Geosci Geomatics 2014; 2(1):28-37.

[34] World Health Organization. Environmental and occupational health hazards associated with artisanal and smallscale gold mining [Internet]. Geneva, Switzerland. 2016. Available from: https://apps.who.int/iris/bitstream/handle/ 10665/247195/9789241510271-eng.pdf? sequence $=1$.

[35] Kairu P. Small miners' love for cheap gold, keeps mercury flowing. East Afr 2020 Apr 30 2020. Retrieved 13th April 2021, https://www.theeastafrican.co.ke/tea/news/east-africa/ small-miners-love-for-cheap-gold-keeps-mercury-flowing1440582.

[36] Rugadya MA. Land tenure as a cause of tensions and driver of conflict among mining communities in Karamoja, Uganda: is secure property rights a solution? Land Use Pol 2020;94: 104495.

[37] Bekhet AK, Zauszniewski JA. Methodological triangulation: an approach to understanding data. Nurse Res 2012

[38] Okalebo R, Gathua K, Woomer P. Laboratory methods of soil and plant analysis: a working manual. In: ResearchgateNet. 21; 2002.

[39] Serwajja E, Mukwaya PI. Condemned to the periphery: the lived experiences of women in artisanal gold mining activities in Karamoja sub-region, Uganda. Extr Ind Soc 2020;7(4): 1511-24.

[40] Ongode B. Mercury in mining: a poisoned chalice. Oil in Uganda; 2014 Nov.

[41] Daily Monitor. Miners warned on the abuse of mercury. Daily Monitor 2019 Feb 27 2019. Retrieved 12th December 2020, https://www.monitor.co.ug/uganda/news/national/ miners-warned-on-use-of-mercury-1810006\#:

: :text=Environmentalists $\% 20$ and $\%$ 20health $\% 20$ experts $\%$ 20have, of $\% 20$ mercury $\% 20$ in $\% 20$ mining $\% 20$ gold.\&text $=\%$ E2 $\% 80 \% 9$ CMercury $\% 20$ has $\% 20$ been $\% 20$ identified $\% 20$ as, to $\% 20$ it $\% 2$ C $\%$ E2 $\% 80 \% 9$ D $\% 20$ he $\% 20$ said.

[42] World Bank. Country reports on mercury trade and use for artisanal and small-scale gold mining [Internet]. Washington D.C; 2016. Available from: http://cegemi.com/wp-content/ uploads/2016/02/Mercury-in-Sub-Saharan-Africa-countryreports-12-December-2016.pdf.

[43] Marc A. Conflict and violence in the 21st Century :Current trends as observed in empirical research and statistics [Internet]. Washington DC. 2016. Available from: https:// www.un.org/pga/70/wp-content/uploads/sites/10/2016/01/ Conflict-and-violence-in-the-21st-century-Current-trends-
as-observed-in-empirical-research-and-statistics-Mr.Alexandre-Marc-Chief-Specialist-Fragility-Conflict-andViolence-World-Bank-Group.pdf.

[44] Esdaile LJ, Chalker JM. The mercury problem in artisanal and small-scale gold mining. Chem Eur J 2018;24(27): 6905-16.

[45] Nakafeero A. Mercury use and practices in artisanal use and small-scale gold mining sector in Uganda. NEMA News; 2019 Jun.

[46] De Vries W, Schütze G, Lofts S, Meili M, Römkens PFAM, Farret R, De Temmerman L, Jakubowski M. Critical limits for cadmium, lead and mercury related to ecotoxicological effects on soil organisms, aquatic organisms, plants, animals and humans. In: Proceedings expert meeting on critical limits for heavy metals and methods for their application. Berlin, December 2-4, 2002. Umweltbundesambt; 2003. p. 29-78. Texte no. 47-3.

[47] United States Environmental Protection Agency. Water: drinking water contaminants [Internet]. 2009. Available from: https://www.nrc.gov/docs/ML1307/ML13078A040.pdf.

[48] World Health Organisation. (Vol. WHO/SDE/WSH/05.08/ 10). Mercury in drinking water [Internet]. 2005. Available from: https://www.who.int/water_sanitation_health/dwq/ chemicals/mercuryfinal.pdf.

[49] Park JD, Zheng W. Human exposure and health effects of inorganic and elemental mercury. J Prev Med Public Heal 2012;45(6):344.

[50] Schaefer AM, Zoffer M, Yrastorza L, Pearlman DM, Bossart GD, Stoessel R, et al. Mercury exposure, fish consumption, and perceived risk among pregnant women in coastal Florida. Int J Environ Res Publ Health 2019;16(24): 4903.

[51] Giang A, Selin NE. Benefits of mercury controls for the United States. Proc Natl Acad Sci U S A 2016;113(2):286-91.

[52] United States Department of Health \& Human Services. Toxicological profile for mercury. Washington D.C. 1999.

[53] Basri Sakakibara M, Sera K. Current mercury exposure from artisanal and small-scale gold mining in Bombana, southeast Sulawesi, Indonesia-Future significant health risks. Toxics 2017;5(1):7.

[54] Bailey M, Bernaudat L. Global extent of mercury use in Artisanal and Small-Scale Gold Mining and why is it a problem? [Internet]. 2016. Available from: https://wedocs. unep.org/bitstream/handle/20.500.11822/12831/12 2 Mercury_Use_in_ASGM_and_Health_Effects.pdf?.

[55] Rossini SR, Reimão R, Lefèvre B, Medrado-Faria M. Chronic insomnia in workers poisoned by inorganic mercury: psychological and adaptive aspects. Arq Neuropsiquiatr 2000; 58(1):32-8. 